\title{
Evaluation on Technological Innovation Capability of Listed Companies Based on
}

\section{the Factor Analysis}

\author{
Huiping Mu, Yaping Huo \\ Management Engineering Department, Zhengzhou University, Zhengzhou, China
}

Keywords: Listed Companies, Technological Innovation Capability, Factor Analysis

\begin{abstract}
One important part of the regional economy is made up of listed companies. Evaluating the technological innovation capability of listed companies can promote the development of listed companies. Firstly, this paper constructed an evaluation index system of technological innovation capability of listed companies from the inputprocess-output perspective. Then, this paper analyzed the technological innovation capability of 64 listed companies in Henan Province based on the factor analysis. In this process, the main factor was extracted, and the comprehensive value of technological innovation capability of each company was calculated and sorted according to their size. Finally, this paper offered proposals on how to improve the technological innovation capability of listed companies in Henan Province based on the analysis of the comprehensive ranking and the ranking of the main factors.
\end{abstract}

\section{INTRODUCTION}

In order to deepen the reform, accelerate the implementation of innovation-driven development strategy, the CPC Central Committee and State Council issued relevant documents in 2015, which emphasized the the market direction function for the direction of technology research and development, the reform route and all kinds of innovative resource allocation. At the same time, it expected enterprises to become the subject of technological innovation decision-making, R\&D investment, scientific research organization and transformation. Therefore, it is of great significance to study the technological innovation capability of enterprises. The state of assets, governance structure and financial system of listed companies are better than other enterprises. To a certain extent, listed companies can partly represent the regional economic and technological comprehensive strength. Economy of Henan Province is lagging behind the rest of the region, so evaluating of technological innovation capability of listed companies is of great significance to promote the development of regional economy in Henan province.

Austrian economist J.

A. Schumpeter first put forward the concept of innovation in 1912, and He defined innovation as a new combination of production functions aimed at pursuing excess profits (Schumpeter J, 1934). Walt Whitman Rostow, an American economist, made a further explanation of the connotation of innovation, and thought that the most important thing in innovation is technological innovation in 1860s (Walt Whitman Rostow,1991). Jiang Wei considered of the technological innovation ability as the guarantee of improving enterprise competitiveness, which can make enterprises located upstream of the value chain and enable enterprises to research and develop products that meet the market demand, then bring great profits to enterprises(Jiang Wei, 1998). Jiaji Fu believed technological capabilities include technological innovation capability, absorptive capacity and production capacity together, but technological innovation capability is the core part of technological capability (Jiaji Fu, 1998.). Ruiqun Wen believes that technological innovation capability means that the enterprises have its core technology in the field, and the ability to realize product value (Ruiqun Wen, 2005). To sum up, scholars and experts have not reached a consensus on the connotation of technological innovation capability. However, in substance, researchers consider that technological innovation capability is essentially a comprehensive ability composed of several elements, which is the sum of many internal conditions for enterprises to implement and complete their innovative behaviors (Fang Wang, 2010).

At present, Most scholars compared and analyzed from the geographical point of view on technological innovation capability of enterprises in Henan province(Junli Li , 2012), or chose the enterprises that belong to the same industry to evaluate(Yanyan Guo, 2011). Although evaluating the technological innovation capability of enterprises in the region can help the government regulate the enterprises macroscopically, its feasibility is relatively low from the enterprise point of view (Lianju Ning, 2011). Evaluating of a certain type of enterprise can guide the industry, but it lacks the overall grasp of the enterprises within the region. This paper selects the listed companies in Henan Province as the research object, taking into account the advantages of the above. Therefore, this paper selects listed companies in Henan Province as the research object.

\section{EVALUATION INDEX SYSTEM OF TECHNOLOGICAL INNOVATION ABILITY}

Although there are many evaluation indicators system of technological innovation ability at present, and what is more, the general evaluation index system has not yet formed, but three perspectives to establish technological innovation capability can be found by reading the literature. The three perspectives are the 
perspective of the components of technological innovation capability, the perspective of input - process output, and the perspective of technological innovation capability system (Shude Shi, 2013). By referring to existing studies this paper constructs the evaluation index system of enterprise technological innovation capability from the perspective of input-process-output, combining with the characteristics of listed companies (Zhengang Zhang, 2012). The hierarchy of evaluation index system of technological innovation ability can not be divided too much, and it's best to be divided into 2 or 4 levels. Under the principles of comprehensiveness, systematicness, scientificity, integrity, comparability, and availability of data, etc. Fifteen specific indexes are selected in this paper, which include innovation support capability, R \& D investment capability, manufacturing and marketing capability, innovation and output capability. Specific indicators are shown in table 1.

Table 1 The evaluation criteria system of technological innovation capability of listed companies

\begin{tabular}{|c|c|c|c|c|}
\hline Target layer & $\begin{array}{l}\text { the first- } \\
\text { grade Index }\end{array}$ & The second-grade index & $\begin{array}{c}\text { Index } \\
\text { code }\end{array}$ & Explanation of index \\
\hline \multirow{15}{*}{$\begin{array}{l}\text { Technological } \\
\text { innovation } \\
\text { capability of } \\
\text { enterprises }\end{array}$} & $\begin{array}{l}\text { innovation } \\
\text { support } \\
\text { capability }\end{array}$ & $\begin{array}{l}\text { The rate of holding share of the senior } \\
\text { executives }\end{array}$ & $\mathrm{X} 1$ & $\begin{array}{l}\text { Total shareholding of senior } \\
\text { executives/The number of shares }\end{array}$ \\
\hline & \multirow{6}{*}{$\begin{array}{c}\text { R \& D } \\
\text { investment } \\
\text { capability }\end{array}$} & The proportion of technical personnel & $\mathrm{X} 2$ & $\begin{array}{c}\text { The number of technical personnel / } \\
\text { The number of employees }\end{array}$ \\
\hline & & $\begin{array}{c}\text { The contribution of technical } \\
\text { personnel to the main business income }\end{array}$ & $\mathrm{X} 3$ & $\begin{array}{l}\text { The main business income/The number } \\
\text { of technical personnel }\end{array}$ \\
\hline & & The intensity of R\& D investment & $\mathrm{X} 4$ & $\begin{array}{l}\text { Research and development } \\
\text { funds/Operating receipt }\end{array}$ \\
\hline & & Per capita R \& D funds & $\mathrm{X} 5$ & $\begin{array}{c}\text { R \& D investment / the number of } \\
\text { enterprise personnel }\end{array}$ \\
\hline & & The proportion of staff training funds & $\mathrm{X} 6$ & $\begin{array}{l}\text { Funds for work expenses and education } \\
\text { funds for workers/The main business } \\
\text { income }\end{array}$ \\
\hline & & The quality of R \& D personnel & $\mathrm{X} 7$ & $\begin{array}{l}\text { The number of undergraduate or } \\
\text { above/The number of employees }\end{array}$ \\
\hline & \multirow{3}{*}{$\begin{array}{c}\text { Manufacturing } \\
\text { and marketing } \\
\text { capability }\end{array}$} & $\begin{array}{c}\text { The degree of manufacturing } \\
\text { equipment input }\end{array}$ & $\mathrm{X} 8$ & $\begin{array}{l}\text { The book value of machine equipment } \\
\text { /The book value of total assets }\end{array}$ \\
\hline & & $\begin{array}{l}\text { The input intensity of technology } \\
\text { assets }\end{array}$ & X9 & $\begin{array}{l}\text { The book value of technical assets /The } \\
\text { book value of total assets }\end{array}$ \\
\hline & & $\begin{array}{c}\text { The input intensity of marketing } \\
\text { expenses }\end{array}$ & $\mathrm{X} 10$ & Selling expenses/Operating receipt \\
\hline & \multirow{5}{*}{$\begin{array}{c}\text { Innovation and } \\
\text { output } \\
\text { capability }\end{array}$} & The number of patents per 100 people & $\mathrm{X} 11$ & $\begin{array}{l}\text { (The number of patents in recent three } \\
\text { years//The number of employees) } \times 100\end{array}$ \\
\hline & & $\begin{array}{c}\text { The growth rate of main business } \\
\text { income }\end{array}$ & $\mathrm{X} 12$ & $\begin{array}{l}\text { (The main business income of this } \\
\text { period -The main business income of } \\
\text { the previous period)/The main business } \\
\text { income of the previous period }\end{array}$ \\
\hline & & The ratio of intangible assets & $\mathrm{X} 13$ & $\begin{array}{l}\text { The value of intangible assets / Total } \\
\text { assets }\end{array}$ \\
\hline & & The growth rate of total assets & $\mathrm{X} 14$ & $\begin{array}{l}\text { The growth of total assets of the } \\
\text { year/Total assets at the end of last year }\end{array}$ \\
\hline & & Earnings per share & X15 & $\begin{array}{l}\text { Net margin/The weighted average of } \\
\text { current and outer common stock }\end{array}$ \\
\hline
\end{tabular}

This showed that the original data selected in this paper was suitable for factor analysis.

\section{FACTOR ANALYSIS OF TECHNOLOGICAL INNOVATION ABILITY}

\section{1 Selected and correlation analysis}

This paper excluded 12 listed companies, which was under special treatment or hadn't incomplete data, then selected 64 A-share listed companies in Henan province as the research object. All the data were derived from the database of Tai'an, cninf, the State Intellectual Property Office website. After standardizing of raw data, factor analysis is carried out. According to the inspection results of KMO and Bartlett, the significant probability of sphericity test of Bartlett was 0, less than 0. 01, and the KMO measure value was 0.667 , greater than 0.5 .

\section{2 Extraction and interpretation of common factors}

As there is no precise quantitative method to determine the number of principal factors, the researchers use some criteria to determine the number of principal factors in practical applications. The principle of eigenvalue, the criterion of broken stone test, the ratio of cumulative variance of explanation, etc. are frequently used. If the eigenvalue principle is applied, the principal component of the eigenvalues greater than or equal to 1 will be used as the initial factor. Table 2 shows that there are 5 factors with eigenvalues greater than or equal to 1 , but the cumulative variance explained by them is 61 . $499 \%$. In practical application, the number of factors generally selected should make the variance ratio of 
cumulative interpretation reach more than $70 \%$ 80\%. The sum of the eigenvalues of the first seven factors accounted for $72.951 \%$ of the total eigenvalue. The first seven factors provided sufficient information for the raw data. In order to make the ranking of factor scores reasonable, seven principal factors were extracted, but When the factor is analyzed, only five factors whose eigenvalues are greater than 1 are analyzed. If the factor is analyzed, only five factors whose eigenvalues are greater than 1 will be analyzed.

Non rotating factor loading matrix can put each variable under the main factors, but the hierarchical relationship is fuzzy, it is difficult to explain the principal component reasonably and represent the common meaning of the original variable. Therefore, the load matrix needs to be rotated so that the factor load is divided into two extremes, highlighting the role of the dominant variable. Finally, a load matrix which is easy to explain the principal component is obtained. Table 3 shows the factor load matrix. The proportion of technical personnel, the intensity of R\&D investment, the quality of R\&D personnel, and the number of patent per 100 people have higher load on the first principal factor(F1), so the first principal factor(F1) could be called R\&D input-output factor. Similarly, the second principal factor (F2) the third principal factor (F3), the fourth principal factor (F4) and the fifth principal factor (F5) were named as the innovation output factor, innovation assets inputoutput factor, innovation management factor and innovation training factor.,

Table 2 Total Variance Explained

\begin{tabular}{|c|c|c|c|c|c|c|c|c|c|}
\hline \multirow[t]{2}{*}{ Component } & \multicolumn{3}{|c|}{ Initial eigenvalue } & \multicolumn{3}{|c|}{$\begin{array}{llll}\begin{array}{l}\text { Extraction } \\
\text { Loadings }\end{array} & & & \\
\end{array}$} & \multicolumn{3}{|c|}{ Rotation Sums of Squared Loadings } \\
\hline & Total & $\begin{array}{l}\% \text { of } \\
\text { Variance }\end{array}$ & $\begin{array}{l}\text { Cumulative } \\
\%\end{array}$ & Total & $\begin{array}{l}\% \text { of } \\
\text { Variance }\end{array}$ & $\begin{array}{l}\text { Cumulative } \\
\%\end{array}$ & Total & $\begin{array}{l}\text { \% of } \\
\text { Variance }\end{array}$ & $\begin{array}{l}\text { Cumulative } \\
\%\end{array}$ \\
\hline 1 & 3.477 & 23.178 & 23.178 & 3.477 & 23.178 & 23.178 & 2.628 & 17.520 & 17.520 \\
\hline 2 & 1.842 & 12. 282 & 35.460 & 1.842 & 12.282 & 35.460 & 1.685 & 11.231 & 28.751 \\
\hline 3 & 1.549 & 10.327 & 45.787 & 1.549 & 10.327 & 45.787 & 1.632 & 10.877 & 39.629 \\
\hline 4 & 1.339 & 8.925 & 54.712 & 1.339 & 8.925 & 54.712 & 1.524 & 10.162 & 49.790 \\
\hline 5 & 1.018 & 6.787 & 61.499 & 1.018 & 6.787 & 61.499 & 1.195 & 7.968 & 57.758 \\
\hline 6 & 0.871 & 5.805 & 67.304 & 0.871 & 5.805 & 67.304 & 1. 143 & 7.623 & 65.381 \\
\hline 7 & 0.847 & 5.647 & 72.951 & 0.847 & 5.647 & 72.951 & 1.135 & 7.570 & 72.951 \\
\hline 8 & 0.767 & 5.116 & 78.067 & & & & & & \\
\hline 9 & 0.721 & 4.808 & 82.875 & & & & & & \\
\hline 10 & 0.621 & 4.138 & 87.013 & & & & & & \\
\hline$\ldots$ & $\ldots \ldots$ & $\ldots \ldots$ & $\ldots \ldots$ & $\ldots \ldots$ & $\ldots \ldots$ & $\ldots \ldots$ & $\ldots \ldots$ & $\ldots \ldots$ & $\ldots \ldots$ \\
\hline 15 & 0.228 & 1.523 & 100.000 & & & & & & \\
\hline
\end{tabular}

Table 3 The factor loading matrix of rotation

\begin{tabular}{|l|l|l|l|l|l|l|l|}
\hline & \multicolumn{7}{|l|}{ Component } \\
\hline & 1 & 2 & 3 & 4 & 5 & 6 & 7 \\
\hline X2 & 0.828 & 0.137 & -0.101 & 0.069 & -0.137 & -0.014 & 0.125 \\
\hline X4 & 0.719 & -0.015 & -0.085 & 0.14 & 0.306 & 0.344 & -0.096 \\
\hline X7 & 0.7 & 0.107 & 0.206 & 0.111 & 0.054 & -0.101 & 0.452 \\
\hline X11 & 0.698 & -0.106 & 0.121 & 0.066 & -0.01 & 0.324 & -0.049 \\
\hline X3 & -0.574 & -0.232 & 0.286 & -0.124 & -0.266 & 0.069 & 0.235 \\
\hline X12 & 0.065 & 0.825 & 0 & 0.142 & -0.049 & 0.013 & 0.082 \\
\hline X14 & 0.06 & 0.791 & 0.141 & 0.017 & 0.09 & 0.004 & 0.201 \\
\hline X13 & -0.091 & -0.087 & 0.862 & 0.059 & -0.006 & -0.03 & 0.023 \\
\hline X9 & 0.056 & 0.241 & 0.766 & -0.055 & 0.049 & -0.042 & -0.081 \\
\hline X8 & -0.228 & -0.027 & -0.259 & -0.718 & -0.044 & -0.075 & -0.274 \\
\hline X10 & 0.074 & 0.054 & -0.123 & 0.709 & 0.347 & -0.103 & -0.012 \\
\hline X1 & 0.081 & 0.349 & -0.155 & 0.632 & -0.237 & 0.323 & -0.269 \\
\hline X6 & 0.069 & 0.015 & 0.055 & 0.135 & 0.9 & 0.064 & -0.031 \\
\hline X5 & 0.176 & 0.025 & -0.06 & 0.038 & 0.056 & 0.873 & 0.112 \\
\hline X15 & 0.03 & 0.301 & -0.11 & 0.056 & -0.061 & 0.124 & 0.796 \\
\hline
\end{tabular}

\section{3 Factor scores and ranking}

According to factor score coefficient matrix, which was worked out by SPSS software, Factor score function could be obtained. then it was multiplied by the weight of each factor to get the comprehensive evaluation score function. In this paper, the variance contribution rate after rotation was chosen as the weight, and the specific score was shown in table 4 .
According to the data in Table 4, the paper analyzed the technological innovation ability of 64 listed companies in Henan province:

According to the ranking of comprehensive technological innovation ability, the paper analyzed the technological innovation ability of Listed Companies in Henan Province. From the regional point of view, the 64 companies are mainly concentrated in the Midwest of 
Henan Province, of which the company in Zhengzhou accounts for about $1 / 3$ of the total number of companies. Similarly, The enterprises with high comprehensive technological innovation ability are mainly located in the Midwest of Henan province. It is obvious that the regional resources have a significant impact on the technological innovation capability of enterprises. The Comprehensive factor score $=\left(0.1752 \mathrm{~F}_{1}+0.1123 \mathrm{~F}_{2}+0.1088 \mathrm{~F}_{3}+0.1016 \mathrm{~F}_{4}+0.0797 \mathrm{~F}_{5}+0.0762 \mathrm{~F}_{6}+0.0757 \mathrm{~F}_{7}\right) / 0.7295$

Table 4 Ranking statistics on the technological innovation ability of 64 listed companies in Henan

\begin{tabular}{|c|c|c|c|c|c|c|c|c|c|c|c|c|}
\hline $\begin{array}{l}\text { Stock } \\
\text { code }\end{array}$ & $\begin{array}{c}\text { F1 } \\
\text { scores }\end{array}$ & $\begin{array}{c}\mathrm{F} 1 \\
\text { ranking }\end{array}$ & $\begin{array}{c}\text { F2 } \\
\text { scores }\end{array}$ & $\begin{array}{c}\text { F2 } \\
\text { ranking }\end{array}$ & $\begin{array}{c}\text { F3 } \\
\text { scores }\end{array}$ & $\begin{array}{c}\text { F3 } \\
\text { ranking }\end{array}$ & $\begin{array}{c}\text { F4 } \\
\text { scores }\end{array}$ & $\begin{array}{c}\mathrm{F} 4 \\
\text { ranking }\end{array}$ & $\begin{array}{c}\text { F5 } \\
\text { scores }\end{array}$ & $\begin{array}{c}\text { F5 } \\
\text { ranking }\end{array}$ & $\begin{array}{c}\mathrm{F} \\
\text { scores }\end{array}$ & $\begin{array}{c}\mathrm{F} \\
\text { ranking }\end{array}$ \\
\hline 300007 & 1. 31 & 7 & 1.40 & 3 & 1.78 & 4 & 0.76 & 13 & 0.41 & 16 & 0.95 & 1 \\
\hline 002046 & 3.67 & 1 & -1.74 & 63 & 1.22 & 6 & -0.91 & 53 & 0.69 & 10 & 0.87 & 2 \\
\hline 300248 & 1.33 & 6 & 0.97 & 6 & -0.37 & 48 & 2.27 & 3 & 1.36 & 4 & 0.81 & 3 \\
\hline 002296 & 2.84 & 2 & 0.24 & 21 & -0.20 & 31 & 0.16 & 25 & -0.33 & 38 & 0.76 & 4 \\
\hline 000544 & 0.45 & 15 & 0.28 & 19 & 4.46 & 1 & -0.39 & 42 & -0.21 & 35 & 0.64 & 5 \\
\hline$\ldots \ldots$ & $\ldots \ldots$ & $\ldots \ldots$ & $\ldots \ldots$ & $\ldots \ldots$ & $\ldots \ldots$ & $\ldots \ldots$ & $\ldots \ldots$ & $\ldots \ldots$ & $\ldots \ldots$ & $\ldots \ldots$ & $\ldots \ldots$ & $\ldots \ldots$ \\
\hline 600595 & -0.09 & 28 & -0.39 & 47 & 0.21 & 12 & -1.08 & 57 & -0.81 & 55 & -0.46 & 60 \\
\hline 000949 & -0.20 & 33 & 0.08 & 28 & -0.89 & 64 & -1.66 & 63 & 0.35 & 20 & -0.48 & 61 \\
\hline 600810 & -0.78 & 55 & -0.99 & 60 & -0.29 & 43 & -0.61 & 47 & -0.46 & 43 & -0.52 & 62 \\
\hline 600531 & -0.87 & 57 & -0.94 & 59 & 0.27 & 10 & -0.17 & 34 & -1.17 & 61 & -0.54 & 63 \\
\hline 600069 & -0.75 & 53 & -0.68 & 56 & -0.18 & 28 & -0.51 & 44 & -0.37 & 41 & -0.58 & 64 \\
\hline
\end{tabular}

Note: only part of the data was listed in this table

On the contrary, most of the industries owned by the latter belong to the excess capacity industry.

According to F1 rankings, Luoyang Bearing Science \& Technology Co., Ltd., Henan Splendor Science\& Technology Co., Ltd., Xuji Co., Ltd., Senyuan Electric Co., Ltd. 's R\&D input-output capability were stronger. Tianan Coal Mining Co., Ltd., Central china land media Co., Ltd., Shuanghui Investment and Development Co., Ltd. and Wanfang Aluminum Manufacturing Co., Ltd. 's R\&D input-output capability were relatively weak. Luoyang Bearing Science \& Technology Co., Ltd. was transformed from the Institute. Henan Splendor Science\&Technology Co., Ltd. was engaged in technology intensive industries. Xuji Co. was the leading enterprise in the power equipment industry. Senyuan Electric Co., Ltd. had a unique technological advantage. The industry Tianan Coal Mining Co., Ltd. and Wanfang Aluminum Manufacturing Co., Ltd. were engaged in were industries with excess capacity. Central china land media Co., Ltd. was engaged in the traditional press and publishing industry. The main business of Shuanghui Investment and Development Co., Ltd. is slaughter and meat processing, so it is not strong in $\mathrm{R} \& \mathrm{D}$ investment compared with high-tech enterprises.

According to F2 rankings, Longhua Heat Transfer and Energy Conservation Co., Ltd., Central China Land Media Co., Ltd., Hanwei Electronics Group Corporation, and Henan Chuying Agro-Pastoral Co., Ltd.'s innovative output capability were stronger. Shen Ma Industry Co., Ltd., Zhengzhou Coal Mining Machinery Group Co., Ltd., Genimous Technology Co., Ltd., and Luoyang Bearing Science and Technology Co.,'s innovative output capability Ltd. were relatively weak. There are many factors that influence the innovation output of a company. Innovative output capability can only finitely reflect the ability of Technological Innovation. Therefore, the ranking of innovation output factor and R \& D input factor was quite different.

According to F3 rankings, Zhongyuan Environmentprotection Co., Ltd., Henan Zhongyuan Expressway first few companies with high comprehensive technological innovation ability belong to high-tech enterprises, so Regional resources have a significant impact on the technological innovation capability of enterprises. The top ranking companies are all high-tech enterprises.
Company Limited, Lotus Health Group Company, and Hanwei Electronics Group Corporation's innovation assets input-output capability were stronger. Zhengzhou Sino-crystal Diamond Co., Ltd., Henan Xinye Textile Co., Ltd., ZYNP Corporation, and Aeolus Tyre Co., Ltd.'s innovation assets input-output capability were relatively weak. Innovation assets input-output factor reflected the intangible assets of an enterprise. In terms of its numerical value, the proportion of intangible assets of the top enterprises was higher, and there was no big difference in the proportion of intangible assets of the latter enterprises. This was related to the business of the company. for instance, Land use right and franchise right accounted for a large proportion of intangible assets in Lotus Health Group Company.

According to F4 rankings, Haoxiangni Health Food Co., Ltd., Sanquan Food Co., Ltd., Newcapec Electronics Co., Ltd., and Henan Lingrui Pharmaceutical Co., Ltd.'s innovation management capability were stronger. Henan Huanghe Whirlwind Co., Ltd., Anyang Iron and Steel Inc ., Zhengzhou Sino-crystal Diamond Co., Ltd., and Xinxiang Chemical Fiber Co., Ltd. innovation management capability were relatively weak. The controlling shareholder of the companies whose innovation management capability is relatively strong was a natural person or legal person, and the actual controller was a natural person. Central state-controlled and local state-controlled enterprises had weak innovation management capability. The former has higher input intensity and managerial ownership ratio than the latter.

According to F5 rankings, Pingdingshan Tianan Coal Mining Co., Ltd., Henan Lingrui Pharmaceutical Co., Ltd., AVIC Jonhon Optronic Technology Co., Ltd., and Newcapec Electronics Co., Ltd.'s innovation training capability were stronger. Xuchang Yuandong Drive Shaft Co., Ltd., Henan Yuguang Gold and Lead Co., Ltd., Henan Tong-da Cable Co., Ltd., and Henan Mingtai Al. Industrial Co., Ltd.'s were relatively weak. The level of an enterprise's training fund investment is part of the 
enterprise strategy, which is related to the management concept of the enterprise. The innovative training capabilities of these companies had not been in line.

To sum up, The companies with strong technological innovation ability in Henan listed companies were concentrated in the central and western regions of Henan province. The technological innovation ability of hightech enterprises is relatively strong. R\&D input-output factors had the greatest impact on the technological innovation capacity of enterprises. There was a big difference in $\mathrm{R} \& \mathrm{D}$ investment between different industries. Innovation output factor had hysteresis in reflecting the technological innovation capability of enterprises, and innovation output factor was easily influenced by macro environment. The central and state owned enterprises in Henan listed companies are inferior to ordinary private enterprises in the flexibility of technological innovation mechanism. The company's cultivation of innovative talents was related to its management concept.

\section{CONCLUSIONS}

Companies belonging to traditional industries should increase R \& D investment. Among the 64 listed companies, manufacturing industry accounted for the vast majority, so in manufacturing enterprises, enterprises producing instruments and meters, general equipment and computers, communications and other electronic equipment had strong $\mathrm{R} \& \mathrm{D}$ investment capability. Enterprises producing food and smelting metals had a weak R \& D investment capability. In non manufacturing enterprises, the ability of R\&D investment of software and information technology service industry is stronger. The ability of R\&D investment of mining industry and cultural communication industry is weaker. Therefore, the traditional industry should increase R \& D investment, improving the technological innovation ability of enterprises.

Enterprises should enhance the ability of transformation of scientific and technological achievements. Because of the hysteresis quality and uncertainty of innovation output, enterprises should strive to enhance the transformation ability of scientific and technological achievements while increasing innovation investment. The company should formulate some incentive policies to reward people or teams who have made outstanding contributions in the transformation of scientific and technological achievements.

Deepening of the reform of State-owned enterprises. The central or state owned enterprises are inferior to ordinary private enterprises in the flexibility of technological innovation mechanism. Increasing the management's shareholding ratio allows the management to share more of the company's profits. That management and the company formed a community of interests is conducive to mobilizing the management of the subjective initiative, then improve the overall performance level and profitability of the company, and form a virtuous circle, prompting enterprises to invest more capital to improve the technological innovation ability of enterprises.

Enterprises should strengthen the construction of talent team, and enhance the core competitiveness of the company. Enterprise innovation comes from employees, and entrepreneurs can help achieve innovative results. The implementation of innovation driven development strategy requires continuous innovation of talents.

Enhancing industrial structure. Nowadays, The excess capacity of coal, cement and aluminum is more prominent, and the market competition is increasingly fierce, So Pingdingshan Tianan Coal Mining Co., Ltd., Henan Tongli Cement Co., Ltd. and Jiaozuo Wanfang Aluminum Manufacturing Co., Ltd. should adjust the structure of industry. These enterprises should be guided by market demand, and focus on transformation and upgrading, and promote the deep integration of traditional business and emerging business, then promote the transformation of development mode and innovation of business model.

\section{REFERENCES}

[1] Fang Wang, Yongan Liu, Jialin He, 2010. Research on technological innovation capability of enterprise. Enterprise economy, (7), pp. 31-33.

[2] Jiaji Fu, 1998. Technical innovation, Tsinghua University press. Beijing.

[3] Jiang Wei, Wu Han, 1998. The definition of enterprise technological innovation capability and its correlation with core competence, scientific research management. (6), 12-17.

[4] Junli Li, 2012. Research on the evaluation and promotion strategy of enterprise independent innovation capability -Taking Henan as an example, China commerce. (17), 243-245. [5] Lianju Ning, Meng Li, 2011. Construction of evaluation model for technological innovation capability of large and medium sized industrial enterprises based on factor analysis, scientific research management. (3), 51-58.

[6] People's Republic of China Central People's government, 2015. The opinions of the Central Committee of the CPC and the State Council on deepening the reform of the system and mechanism and speeding up the implementation of the strategy of innovation driven development.

[7] Ruiqun Wen, Jianli Gong, 2005. Wang Lina. Research on Evaluation of enterprise independent innovation capability, Group economic research. (9), 68-69.

[8] Schumpeter J, 1934. The Theory of Economic Development, Harvard University Press. Cambridge.

[9] Shude Shi, 2013. Reviews and reviews on the evaluation of enterprise technological innovation capability. science and technology management research. (10), 13-16.

[10] Walt Whitman Rostow, 1991. The stages of economic growth --A non-communist manifesto, Cambridge University Press. Cambridge.

[11] Yanyan Guo, 2011. Evaluation of independent innovation capability of large and medium sized enterprises in Henan based on KCI method. China business. (28): 225-228.

[12] Zhengang Zhang, Shaoxian Zheng, 2012. Evaluation of technological innovation capability of large and medium sized industrial enterprises in China -- Taking Guangdong Province as an example, Technical economy. 31(9), 1-6. 